\title{
Artistic Competitions at Greek Olympia Games in the 19th Century
}

\author{
Hisashi Sanada \\ Institute of General Human Sciences, University of Tsukuba \\ 1-1-1Tennodai, Tsukuba-shi, Ibaraki 305-8574 Japan \\ [Received March 4, 2009; Accepted June 3, 2009; Published online December 10, 2009]
}

\begin{abstract}
The purpose of this study is to examine ideas concerning artistic competitions and the competition content at Greek national Olympia Games in the nineteenth century. The following conclusions were reached: The first Greek national Olympia Games in 1859 had athletic competitions and an industrial exposition. Some artistic products were found among the industrial products and prizes were awarded for some artistic works. In 1870, vice president of Olympia Committee suggested that artistic and intellectual competitions should be included in the Olympia program to unite body, intelligence and industry for the development of culture and society with worship of the Muses. Artistic competitions were staged as an element of industrial products competitions in the second and the third Greek national Olympia Games. These artistic competitions were in the architecture, painting, sculpture, literature and music categories. Artistic and intellectual competitions were staged at the fourth Olympia Games in 1888. It can be said that the artistic competitions were derived from the industrial products competitions and they developed widely. Greek people who lived in foreign countries supported these artistic competitions and they also supported the first international Olympic Games. During the first international Olympic Games in 1896, a music competition was announced and many kinds of artistic events were held by the Greek Organizing Committee. They became part of the Olympic legacy of the national Olympia Games. The revival of the Olympia Games by the Greek people was not limited to athletic competition but also included artistic competition. The principles of these artistic competitions sought a merger of the body and the mind.
\end{abstract}

Keywords: Artistic Competition, modern Greece, Olympia Games, 19th Century

[International Journal of Sport and Health Science Vol.7, 23-30, 2009]

\section{Introduction}

Artistic competitions in the modern Olympics were first proposed by Pierre de Coubertin (1906) in 1906 as a means of "reuniting the muscles with the mind," and were first staged at the fifth Olympic Games in 1912. There were five artistic competitions: architecture, sculpture, painting, literature, and music. Coubertin (1934) believed that these arts are connected to the Muses, i.e., the goddesses of music, literature and dance, and referred to them as the "Pentathlon of the Muses."

Artistic competitions were also staged in Athens 50 years before the fifth Olympic Games. They were staged in the national Olympia Games in Greece in 1859, 1870, 1875 and 1888. The events were not limited to athletics, but also included industrial competitions and expositions.

In earlier studies about the national Olympia Games in Greece, research was conducted about the athletic competitions, but no attention was paid to the exhibitions of industrial products. The artistic elements, however, were included in the competitions of industrial products. The event including competitions of both sports and industrial products was named "Olympia". Therefore, the industrial products and artistic competitions should also be examined in detail.

Based on the above, the purpose of this study is to clarify the ideas and content of the artistic competitions in the national Olympia Games in Greece during the nineteenth century. 


\section{Artistic Competitions in the First Olympia Games (1859)}

\subsection{The Olympia Games Revival Plan of 1835 and Artistic Competitions}

The first proposal of the revival of the Olympia Games after independence from Turkey was suggested by the poet Panayotis Soutsos (1806-1868) and Minister of Interior Ioannis Kolettis (1773-1847) in 1835. Soutsos was born in Constantinople and was educated in Paris and Vienna from 1820 to 1823. In 1833, he moved to Nafplion, which was the first capital of Greece after the country became independent and he published a newspaper "Ilios".

In 1835 , Soutsos proposed to Kolettis, with whom he had become friendly during the war of independence, that they should revive the ancient Olympic Games and make March 25 a national holiday to mark the beginning of the war. Kolettis was one of the leaders of the war of independence, and he agreed to institute the "Greek public Games" including the following. (Georgiadis 2003 p.28)

- Athletic competitions: ancient athletic events including chariot race, horse race, running and wrestling

- Industrial exposition: agricultural products and tools, and industrial products

- Artistic competitions: philosophy, literature, paintings, sculptures, and chorus

- Games to be held at Athens, Tripolis, Mesolongion, and Hydra in turn.

- Prize to be awarded to the winners of each competition.

Thus, Minister Kolettis agreed to hold athletic competitions as well as industrial product and artistic competitions. Poet Soutsos sought to introduce artistic competition into the Games to revive art in modern Greece like as paintings and sculptures had decorated sacred Olympia. Based on the plan by Minister Kolettis, the revival of the ancient Games was regulated by law. A royal decree on establishment of the "Committee for the Encouragement of National Industry" was proclaimed in February 1837. The introduction of the decree provided that the Games sought to promote agricultural and industrial development and to nurture local specialty products. Twelve committee members were appointed to hold the event under the leadership of the Ministry of Interior. Article 34 of the decree referred to the revival of ancient athletics:

"Three days of athletic events shall be held during the games and shall include horse racing, wrestling, running, discus throwing, jumping, javelin throwing, folk dancing, and other athletics as well as chorus and symphony music. These competitions will be performed according to the events program and the rules set up by the committee and each victor will be given a crown of laurel". (Official Gazette, 1837, pp. 1-8)

The artistic section of this regulation refers only to folk dance, chorus and symphony music, but they are not mentioned as being in competitive formats. Thus, this initial decree of the Greek government did not place any particular emphasis on artistic competition.

\subsection{Royal Decree on Institution of the Olympia in 1858 and Artistic Competition}

The Games specified in the royal decree of 1837 were not held because of financial problems. Soutsos again proposed a revival of the Olympic Games in "Ilios" (July 15, 1856). He referred to the following three types of competition.

- Athletic competitions (chariot races, horse races, wrestling, and so on)

- Exhibitions of industrial products and ancient literature

- Artistic competitions (epic poetry, lyric poetry, poetry such as a tragedy, and history)

Kolettis has died in 1847 , but Soutsos proposed three types of competition as under the plan of 1835. Soutsos also insisted that artistic competitions including literature and history should be held in the Games. A wealthy man named Evangelis Zappas (1800-1865) agreed to the plan to revive the Olympic Games and wrote a letter to King Otto stating that he would pay all expenses by donating his asset to the government. A royal decree on the "Institution of Olympia Games" was adopted in August 1858.

This decree stated that the national games named "Olympia" would be held in 1859 for the development of the nation. It was stated in the decree that a comprehensive competition "Olympia" would be held in Athens every four years and that exhibition of Greek work, agricultural, industrial, and animal husbandry products as well as horse race and athletic competitions would be held. Article 16 stated as follows with respect to the artistic competitions:

"On the final day of the Olympia there will be 
awards ceremony for industrial products, and the victors shall be awarded a wreath of leaves. Theatrical works shall be performed in the new theater and works of music shall be played in the Academy, followed by the awarding of a wreath of leaves to the victors." (Official Gazette, 1858, p. 2)

The 1858 decree was referred only to theater and music with respect to artistic competition. The categories of industrial products, however, included artistic works. Awards were presented for gold working, musical instrument manufacture, painting, sculpture, and architecture. (Greek Biographical Lexicon, 1962, p. 399)

The Greek government at this time believed that competitions in harmony with civilized society were industrial product competitions that would spur economic and social development. The government was implementing modernization program and intended for the Olympia Games to focus on industrial exhibitions. In contract to this, Soutsos and other supporters sought to revive the ancient tradition including not just athletic competitions, but also artistic competitions. The government created a new industrial exhibition and constructed a hall for the exhibitions, while Soutsos and other intellectuals put considerable efforts into restoring the ancient competition site in Athens and restoring artistic competitions.

\section{Artistic Competitions in the Second and Third Olympia Games}

\subsection{Artistic Competitions in the Second Olympia Games (1870)}

The exhibition of industrial items at the second Olympia Games opened on November 1, 1870. A speech by Demetrios Christidis, vice president of the Olympia Committee, indicated a new direction for the Olympia Games. He explained that the objective of creating the Olympia Games was not limited to the initial concept of industrial development, but also included bodily vigour, intelligence, worship of the Muses, and social objectives. He said that they had entered a stage of progress, within physical competition and logical intellectual training including industry that human operated as social animals. (Chrisafis, 1930, pp.75-76)

Christidis raised worship of the Muses, the goddesses of art and music, and stated that the principles of the Olympia Games were physical competition, intellectual training, and the development of society through the merger of the two and industry.

Ioannou Philippos, a professor at Athens University, also expressed similar ideas. Ioannou stated that when the Olympia Games was held, a library was built, an academy was created, and educational levels in Greece were raised. He also stated after Greece became independent that prizes should be granted to individuals who contribute to the development of the nation's intellectual fields (literature, history, archaeology, poetry, linguistics, and so on). He also asserted that it was essential to raise the morals of the people. (Olympia Committee 1872 pp. 153-154)

The speeches of Christidis and Ioannou emphasize that the second Olympia Games was characterized not only by athletic competition and industrial elements, but also development in intellectual and artistic fields such as literature, history, poetry, and the arts. The indications of respect in the arts and literature in addition to the development of industry are important for a modern interpretation of the ancient Olympics and their traditions. Ancient competitions included artistic competitions, such as music and poetry readings. Strictly speaking, artistic competitions were not held at Olympia, but there were conducted at other Panhellenic events such as Delphi, Isthmia, and Nemea. In addition, the Temple of Zeus and Altar of Hera built at the sacred Olympia site were in the architectural style of the time, and displays of works by numerous artists such as sculptures of Zeus with a height of 8 meters in the sacred place. Also, Pindaros and Baccyrides, who were active in the fifth century $\mathrm{BC}$, wrote poems to winning athletes that have been handed down to later generations.

Christidis and Ioannou intended for the Olympics to result in cultural and social advancement, just like that ancient Olympics.

Athletic competitions at the second Olympia Games included running, long jump, triple jump, discus throwing, javelin throwing, wrestling, mast climbing, rope climbing, and other events held at the restored site of the ancient Panathenaic Stadium.

The display of industrial products included an artistic division, and awards were presented to the outstanding entries. The works were in the five categories favored by the Muses: sculpture, painting, architecture, poetry, and music.

There was a total of 80 industrial product types in 10 categories, and each type was awarded a prize. An explanatory document prepared by the local 
government that selected each item was submitted for review.

Similar to the agriculture, animal husbandry, and mining categories for the industrial products, categories were also created for the artistic works. An exhibition of oil paintings, water colors, sculptures, architecture (designs), lithographs, and copperplate prints was held. Competitions of poetry and music were also held independent from the competitions of industrial goods. (Olympia Committee, 1869, pp. 7-11)

In this way, artistic competition was established at the Greek Olympia Games.

In the sculpture category, 59 works by 10 artists were entered. In painting, 48 works by 16 artists. In architecture, the Olympic Committee reported that five individuals submitted works. One of these 31 people was a woman from Constantinople. (Georgiadis, 2003, p.41) This expressed the relationship in the arts between the lives of ancient Greeks and those of modern Greeks, and in particular the awareness of the Greek people concerning the relevancy of culture and the war of independence. Eight sculptures, 10 paintings, and one architectural design were selected for prizes. (Olympia Committee, 1872, pp.12-13)

In this manner, artistic competitions were held at the second Olympia Games to honor the Muses and competitions in painting, sculpture, architecture, music and poetry were held.

\subsection{Artistic Competitions in the Third Olympia Games (1875)}

The Third Olympia Games were held in May 1875. As was the case at the second games, the athletic events were held at the Panathenaic Stadium and included the triple jump, long jump, wrestling, discus throwing, javelin throwing, and pole vault. In the industrial competitions, there were 95 industrial product types in 16 categories. (Olympia and Bequest Committee, 1875, pp. 3-13) A total of 1,200 products were submitted from throughout Greece, and 72 products were submitted from other countries, resulting in an impressive industrial exhibition. The foreign submissions came from Paris, Rome, Copenhagen, Alexandria, and Constantinople. In addition, Greek contingents came to Athens from Crete, Thessaloniki, Serres, and other territories that were under Turkish jurisdiction at that time.

The opening ceremony for the industrial exhibition was held on May 5, 1875. At the ceremony,
Anagnostakis A. of Athens University gave a lecture on the intellectual development of the country over the past four years. (Anagnostakis, 1875, pp.3-35) S.Tsivanopoulos a professor at Athens University, gave a special lecture on academic advances by Greeks from research on ancient Greek and Roman literature, architecture, philosophy, history, modern Greek literature, and poetry. (Olympia and Bequest Committee, 1876, pp.211-218) They stressed the development of the intellectual and cultural aspects through the Olympia Games.

The artistic competitions included architecture, painting, and sculpture as well as musical instrument manufacture and musical performance. There were also poetry competitions.

The deadline for the poetry competition was January 31, 1875. (Olympia and Bequest Committee, 1875, p.3) On the opening day at the Zappeion Exhibition Hall, Tsivanopoulos announced the poems written by poets over the four year Olympiad (1871 to 1875) as a commemoration to the advancement of the Greek people.

In addition, the poems of individuals who contributed to the Olympia Games such as Soutsos and others were put to music at these Olympia Games. Soutsos wrote a "Hymn of Praise to My Hometown". This song contains the line "Lets us bring the Children of Greece to Olympia, to ancient times/Greece, a brilliant future, a wonderful palace". (Olympia and Bequest Committee, 1875, p. 5) Putting these poems to music can be seen as handing down the spirit of persons associated with the Olympia Games.

In the sculpture and painting categories, a total of 18 works won prizes. (Olympia and Bequest Committee, 1876, pp. 310-312) The silver medal (first place) in sculpture went to a Greek called Halepas who lived in Munich for a work on the theme "The Satyr and Eros". There was a problem among the committee members when selecting the works, and as a result, an art professor was excluded from the awards committee. (Olympia and Bequest Committee, 1876, pp. 309-310)

This incident shows the difficulty in assessing the quality of artistic works. One of the reason that artistic competitions were ended in the modern Olympics was difficulty with the assessment standards, and this problem arose in the Greek Olympia Games as well.

Olympia Committees were also established by local governments, and these committees playing a central role in determining the works to be submitted was one of the features of the third games. After its creation as a 
national event, the Olympia Games gradually became established as a network of city and village Olympia Committees and committees that functioned as ethnic committee for Greeks living overseas, supporting the Olympia Games. Participation in the 1875 Games was from Europe as a whole as well as the Mediterranean and Middle East regions, and it served as an opportunity for the creation of networks among Greeks in various fields.

Close ties were created among Greeks from various regions including friendly relations, exchanges of information, and promotion of the arts. This was also seen in the first modern Olympic Games held in 1896. G.M.Averoff (1818-1899), a resident of Alexandria, provided massive funding for holding international Olympic Games in Athens.

\section{Artistic Competitions at the Fourth Olympia Games (1888)}

\subsection{Regulations on the Artistic Competitions at the fourth Olympia}

The fourth Olympia Games included not only artistic competitions, but intellectual competitions as well. Following the death of Evangerlis Zappas (1800-1865), an avid supporter of revival of the ancient Olympics, Konstantinos Zapppas (1814-1892), his cousin and heir to his intentions and assets, provided funds for construction of a headquarters for the Olympia Committee and an exhibition hall for the industrial exhibitions, and construction was completed in 1888 . Konstantinos Zappas asserted that Evangerlis Zappa's will required revival of artistic competitions such as drama the same as athletic competition, just as was done at the ancient Olympics. (Greek Biographical Lexicon, 1962, pp. 416-417) When holding the Olympia Games and constructing the Zappeion, the Greek government and the organizing committee, which relied on funding from the Zappas family, accepted his opinion. A royal decree on "Completion of the Zappeion and Holding of the Fourth Olympia Games" was issued in January 1888, and preparations went forward. (Olympia and Bequest Committee, 1888, pp.1-3)

The royal decree held that a ceremony marking the completion of the Zappeion and the opening ceremony of the fourth Olympia Games would be held on the second Sunday of October 1888 with funding from Evangerlis Zappas and Konstantinos Zappas (Article
1), that industrial product, painting, and sculpture competitions would be held, and that ancient theater and intellectual competitions would be held in accordance with the request of Konstantinos Zappas (Article 3), and that the closing ceremony would be held in the final Sunday of October (Article 4).

In accordance with the royal decree, the Olympic Committee issued detailed rules for each competition in the name of committee President S.Dragoumis. An overview of the rules is as follows (Olympia and Bequest Committee, 1888, pp.1-7).

- Rules concerning the Evangelis Zappas Intellectual Competition (March 4, 1888)

Articles with the following content on the theme "Greece's Forests" will be solicited.

a. Use of the forest and configuration of the soil.

b. Botanical surveys concerning Greece's forests and coasts.

c. The status of forests (land area and destruction of forests).

d. Competitors could submit works from July 20 to August 1, 1888.

- Rules concerning the Konstantinos Zappas Drama Competition (March 4, 1888)

a. The main content of the drama should be about Greek history in ancient times, the middle ages, or modern Greece prior to 1821.

b. The drama must be in verse, from three to five acts, and 300 lines or more.

c. The manuscript must be easy to read and no modifications will be permitted. Dramas must be submitted to the president of the Olympia committee between July 20 and August 1, 1888 .

d. The dramas will be screened by three committee members and selected starting on August 1, 1888. The results will be announced at the main hall during the opening ceremony of the fourth Olympia Games.

e. The author of best work will be presented a prize of 1,000 drachmas, and the drama will be performed during the Games by the Olympia Committee.

- Rules concerning the Nikolaidis Filadelfeos Poetry Competition (April 19, 1888)

This competition was created in response to a proposal by amateur artist Nikolaidis Filadelfeos, who wanted to express the true spirit of the Greek people. 
(It later become name as the Filadelfeos Poetry Competition.)

a. The competition is limited to lyric poetry.

b. The poems must be between 400 and 800 lines.

c. The poems must be received by the Olympia Committee by August 15, 1888.

d. The poems will be screened by three members of the Olympia Committee, and the results will be announced on a set date at the Zappeion Hall.

e. The author of best work will be presented a prize of 1,000 drachma.

- Rules concerning the Music Competition (May 17, 1888)

a. Two types of competition will be held. The first is composition of a march, dance, war song, symphony, opera.

b. The winning piece will be performed in a public place.

c. The second music category is competition between performing groups such as military bands or local orchestras. Each group would perform two works, and one was selected by the committee.

From these rules, we can make the following observations concerning that nature of the artistic competitions in 1888.

There was particular emphasis on Greek history in ancient times, the middle ages, or modern Greece prior to 1821 , as seen in the rules concerning drama.

The winning submissions were given substantial prizes of 1,000 drachmas, showing the significance that the Olympia Committee and other involved persons placed on the artistic competitions.

The Olympia Games artistic competitions were approaching the concept initially put forward by Soutsos and the others (philosophy, literature, painting, sculpture, and music).

\subsection{Holding the Artistic Competitions}

A ceremony marking the completion of the Zappeion Hall and the opening ceremony of the fourth Olympia Games were held on October 20, 1888. The added artistic competitions were praised as providing opportunities for young writers, poets, composers, and other artists to work in their fields. ("Akropoli" 1888.)

The winner of the poetry competition was Kostis Palamas (1859-1943), a representative Greek poet who wrote "Hymn to Athena". Palamas wrote the Olympic Hymn for the 1896 Athens Games. This Olympic Hymn continues to be performed at Olympic Games even today.

The winner in the 1888 painting category was $\mathrm{N}$. Gyzis (1842-1901). He later worked on certificates and posters for the Athens Games in 1896. J.Kaisaris, who submitted a work in the music category, wrote the March for the Athens Games in 1896. The 1888 Olympia Games also led to the formation of a nationwide drama organization.

The artistic competitions also resulted in considerable identification with the Olympia Games by Greeks living overseas. The Olympia Games were well known among Greeks living overseas, and many not only observed the games, but also supported them. (Georgiadis 2003 p.48)

Many Greeks followed the example of Zappas and gave prizes to the Olympia Games. I.Pesmatzoglou, a resident of Alexandria, provided a monetary prize of a certain amount for paintings in the artistic category. Olympia Committee gave the prize to a Greek painter living overseas.

In the sculpture category, a contest was held for a statue of Lord Byron, who died for the Independent War. The funds were provided by A.S.Skylitsis, a Greek living in Constantinople. He wanted to beautify Athens with this type of statue.

A Greek organization in Trieste donated 5,000 drachma for the winner of the musical performance competition. Thus, donations were made by both individuals and organizations. In this way, holding the artistic competitions served to raise interest in the Olympia Games and secured numerous sponsors for the Games.

\subsection{Artistic Competitions and Cultural Events in the Modern Olympics}

The artistic competitions of the Olympia Games were to be continued in the 1896 First Olympic Games in Athens. The organizing committee included music competition and cultural events in the plans. For the music competition, performances by each group were scheduled for the afternoon of the seventh day of the Games. Bad weather on the seas, caused groups from other areas to arrive later, and performances were cancelled. (Coubertin et al., 1897, pp. 99-100) That evening, seven groups performed while marching along a boulevard in the city. The seven groups were musical 
groups from Laurium, St.Maura, Cephalonia, Zante, Corfu, the Athens Symphony Orchestra, and the Royal Navy Band. (Coubertin et al, 1897, p.103)

The British athlete George Robertson, from the Oxford University read an ode in ancient Greek in the awards ceremony. He composed it in Pindaric meter to celebrate the Olympic Games. The king awarded him a laurel branch in the awards ceremony. (Coubertin et al., 1897, p.111, p.114) Laurel was one of the prizes in the ancient artistic competitions in the Pythian Games at Delphi. (Kyle, 2007, pp.138-139) Central Greece including Delphi was the home of the Muses. We can say that Robertson was praised as well as a winner of the poetry competition.

Also, the ancient drama Antigone by Sophocles was performed at an Athens theater on the sixth day of the Games. (Papadopoulos 1989) There was also a concert by the Athens Symphony Orchestra and torch processions in Piraeus and Athens during the Games. (Coubertin et al., 1897, p.92, pp.102-104).

L.Nikiphoros, winner of the 1859 Olympia Games painting competition, designed the medals for the Athens Games. (Georgiadis, 2003, p. 36)

In this way, the athletic competitions and cultural events held at the first modern Olympics in Athens were conducted by Greeks themselves. This was the legacy of the Olympia Games held independently in Greece.

\section{Conclusion}

Since 1835 when Soutsos first proposed a revival of the ancient Olympic Games, it was contemplated that the Games would include both athletic and artistic competitions. Sculptures, paintings, and other artistic works were displayed in the competitions of industrial products at the first Olympia Games held in 1859.

In 1870, Vice President Christidis of the Olympia Committee asserted that the objectives of the Games were just national unity, but also promoting "bodily vigour" and "worship of the Muses," giving considerable attention to competition in the artistic and intellectual fields. He believed that the principles of the Olympia Games were physical competition, intellectual training, and the development of society through the merger of the two. Based on this, artistic competitions (architecture, painting, and sculpture) were held at the second and third Olympia Games as a division of the industrial product competitions and were established as a part of the Games. Music and poetry competitions were also held separate from the industrial products.

At the fourth Olympia Games in 1888, Konstantinos Zappas pushed for further development of the artistic competitions, and drama and intellectual competitions were also held. It was understood that holding various artistic competitions was necessary for a revival of the ancient Olympic Games.

In addition, holding the artistic competitions not only contributed to the development of drama, poetry and music within Greece, but also served to promote the formation of international networks among Greeks through the support of overseas Greek residents and organizations as sponsors. This served as an economic foundations for the later first modern Olympic Games in Athens.

It should also be noted that the artistic competition was to be continued at the 1896 Olympic Games. Music competition was announced and many kinds of the cultural events were held at the Athens Games.

It is often said that artistic competitions in the modern Olympics began with the fifth Olympic Games in 1912, but in fact they were conducted at the Greek Olympia Games. The artistic competitions favored by the Muses were held starting in the 1870 Olympia Games. The revival of the Olympia Games by the Greek people, like the modern Olympics, was not limited to athletic competition but also included artistic competition. The principles of these artistic competitions sought a merger of the body and the mind.

\section{References}

Anagnostaki A. (1875). Speech on Olympia. Athens: Typografia ton Adron Perri. pp.3-35 (in Greek).

Chrisafis I.E. (1930). Contemporary International Olympic Games. Athens: Tipis Sergiadou. pp.75-76 (in Greek).

Coubertin P., Philemon T., Politis N.G., \& Anninos C. (1897). The Olympic Games; B.C.776.-A.D.1896. Second Part; The Olympic Games in 1896. Athens: Charles Beck, p. 92, pp. 99-104, 111, 114.

Coubertin P. (1906). A great marriage. In Pierr de Coubertin, Olympism. Lausanne: International Olympic Committee, p. 632.

Coubertin P. (1934). Forty years of Olympism. In Pierr de Coubertin, Olympism. Lausanne: International Olympic Committee, p. 743.

Georgiadis K. (2003). Olympic Revival; the revival of the Olympic Games in modern times. Athens: Ekdotike Athenon S.A. p. 28, $41,48,51$.

Great Greek Biographical Lexicon (1962). Vol. 1. p. 399, pp. 416-417 (in Greek).

Kyle D.G. (2007). Sport and spectacle in the ancient world. Blackwell Publishing: Oxford, pp. 138-139.

Newspaper "Akropoli" Athens, 1888.10.24 (in Greek).

Newspaper "Ilios" Athens. 1833.7.4, 1856.7.15 (in Greek).

Official Gazette (1837). Athens. pp. 1-8, pp. 17-20 (in Greek). 
Sanada, H.

Official Gazette (1858). Athens. p. 2 (in Greek).

Olympia Committee (1869). Royal Decree, Circulars, Testament of Evangelis Zappas and Regulations of the Olympia for 1870. Athens: Ethniki Typografia. pp. 7-11 (in Greek).

Olympia Committee (1872). Second Olympia in 1870. Athens: Ethniki Typografia. pp. 2-11, 12-13, p. 153, 154, pp. 173-175 (in Greek).

Olympia and Bequest Committee (1875). Third Olympia: each regulations on category of industrial exhibition. Athens. pp. 3-13, 62 (in Greek).

Olympia and Bequest committee (1876). Olympia in 1875. Athens. p. 183, 211-218, 309-312, 349 (in Greek).

Olympia and Bequest Committee (1888). Competitions in the forth Olympia. Athens. pp. 1-7 (in Greek).

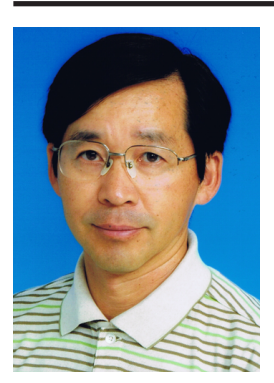

Name:

Hisashi Sanada

\section{Affiliation:}

Institute of General Human Sciences, University of Tsukuba

\section{Address:}

1-1-1 Tennodai, Tsukuba-shi, Ibaraki 305-8574 Japan

Brief Biographical History:

1979-1981 Masters program in Health and Physical Education, University of Tsukuba.

1990-1996 Associate professor at Fukuoka University of Education 1999-2008 Associate professor at University of Tsukuba

2008- Professor at University of Tsukuba

Main Works:

- 'The Most Polite Savages'-The Participation of Ainu in the 1904 St. Louis Olympic Games-. Andreas Niehaus (ed.) Olympic Japan. Wuerzburg: Ergon Verlag, pp. 133-149, 2007.

- Reorganization of Suijutsu led by Kano Jigoro. Japan J. Phys. Educ. Hlth. Sport Sci. 52: 315-326, 2007 (in Japanese).

Membership in Learned Societies:

- Japan Society of Physical Education, sport and Dance.

- Japan Society of Sport Anthropology

- Japanese Society of Sport Education

- Japan Olympic Academy

- North East Asian society of history of Sport and Physical Education 